\title{
仕上げ材を施すコンクリート床スラブの含水率，細孔構造 MOISTURE CONTENT AND POROSITY OF SUBSTRATE CONCRETE FLOOR SLABS FOR FINISHING MATERIALS
}

\author{
湯 浅 昇*, 笠井芳夫**, 松井 勇**, 逸見義男 ${ }^{* *}$, 佐藤弘和**** \\ Noboru YUASA, Yoshio KASAI, Isamu MATSUI, \\ Yoshio HENMI and Hirokazu SATOH
}

\begin{abstract}
Pore structure and moisture content of concrete slabs with different water-cement ratio and drying conditions were studied to find the appropriate curing conditions for floor finishings.

Decrease of moisture content of concrete within $2.5 \mathrm{~cm}$ from the drying surface was conspicuous and a portion $0.5 \mathrm{~cm}$ below the surface reached $2.5 \%$ within 14 days whereas a portion deeper than $7.5 \mathrm{~cm}$ was almost unchanged after the self desication was matured.

The densification of pore structure owing to the hydration of cement was possible when a finishing was applied at the age of 1 day, whereas no densification was observed leaving coarse pores due to an insufficient hydration when a finishing was applied after 3 days.

In order to solve an incompatibility for a concrete slab to assure sufficient hydration for strength and durability and sufficient drying as a substratum of finishings, it is recommended to have a moist curing for 7 days after placing followed by a drying.
\end{abstract}

Keywords: Concrete slab, Finishing, Drying, Curing, Moisture content, Porosity コンクリートスラブ、仕上げ材、乾燥、養生、含水率、細孔構造

\section{1.はじめに}

構造体コンクリートは、乾燥を受けるとコンクリート表層部から 含水率が低下する。若材齢で乾燥を受ければ、セメントの水和は阻 害され、表層部のコンクリートほど細孔構造は粗いまま残存する ${ }^{1) 。}$ 打設直後から乾燥を受けることの多い床スラブ（以下ここでは単に スラブと表現する）は、他の部材に比ベ、この現象が顕著に生じる と予想される。また、このコンクリートに仕上げ材を施工すると、 表面からの乾燥が緩慢となるか、または停止する。これに伴い、コ ンクリート内に水（水蒸気）の再拡散（再配分）が起こり、再び水 和が進行することも考えられる。

コンクリートスラブに施した防水層や各種床材にみられる剥離、 ふくれ、変質等の劣化現象は、コンクリートスラブの品質と深いか かわり合いがあると考えられており ${ }^{2-9)}$ 、スラブの品質を工学的に 理解することは重要である。しかしながらコンクリートの含水率測 定の事例 ${ }^{10)-14)}$ は多少あるものの、コンクリートスラブの品質が 十分理解されていないのが現状である。コンクリートスラブは、他 の部材とともに構造上及び、耐久性の観点から、J A S S 5 によっ て初期湿潤養生が規定 ${ }^{15)}$ されている。一方、仕上げ材の下地とし $\tau$ J A S S 8 ${ }^{16)}$ 、合成高分子系床仕上げ施工指針・同解説 ${ }^{17}$ 及び

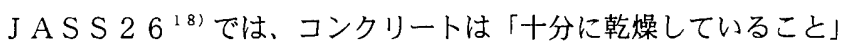

が要求されている。これらの規定の中では、湿潤盖生の必要性は漠 然としか論じられていないこともあり、ややもするとコンクリート 表面を乾燥することに重点が置かれることが多いのが現状である。 そこで本研究は、仕上げ材を施すコンクリートスラブについて、 構造体及び仕上げ材の下地としての両面からコンクリートの含水率、 細孔構造を観祭し、仕上げ材を施工するコンクリートスラブの適正 な養生の指針を得ようとするものである。コンクリートの含水率は、 仕上げ材を施工する打設面からの深さに応じて、あらかじめ筆者ら が開発したセラミックセンサ ${ }^{19)}$ を埋め込み測定した。また、細孔 構造は、打設面からの深さに応じてコンクリート試料を採取し、こ れを用いて水銀圧入法により測定した。

\section{2. 打設直後より乾燥を受け、その後不透湿な仕上げ材を施工した} コンクリートスラブの含水率、細孔構造の変化

ここでは打設直後より乾燥を受けるコンクリートの含水率及び細 孔構造の経時変化について検討する。

\section{1 実験概要}

（1）試験体の作製

a. コンクリート及び乾燥条件

$\mathrm{M}$ 社製普通ポルトランドセメント（比重3.16）、大井川水系川砂

\footnotetext{
本論文は参考文献22)で発表した発表論文に新たなデータを加え，まとめたものである。

* 日本大学生鷹工学部建築工学科 助手・ 工隹

** 日本大学生应工学部建築工学科 教授. 工博

*** 日本大学生産工学部建築工学科 非常勤茀師

侏タジマ技術部 工修

Research Assoc., Dept. of Architecture and Architectural Eng., College of Industrial Technology, Nihon Univ., M. Eng.

Prof., Dept. of Architecture and Architectural Eng., College of Industrial Technology, Nihon Univ., Dr. Eng.

Part-time Lecture, Dept. of Architecture and Architectural Eng., College of Industrial Technology, Nihon Univ.

Staff Engineer, Technical Division, Tajima Incorporated, M. Eng.
}

(元日本大学大学院生産工学研究科 大学院生) 
（表乾比重2.62、粗粒率2.83）、大井川水系川砂利 （表乾比重2.66、粗粒率6.96）及びN社製 A E 減水 剤を使用し、表- 1 に示す調合によりコンクリート を練り混ぜた。このコンクリートを用いて図-1に示 すスラブを想定した含水率測定用試験体 $\mathrm{A} （ 15 \times 15$ $\times 50 \mathrm{~cm})$ と、細孔構造の測定用試験体 $\mathrm{B}(\phi 10 \times 15$ $\mathrm{cm})$ の 2 種類の試験体を作製した。試験体の打設は $20^{\circ} \mathrm{C} 、$ R. H. $60 \%$ の恒温恒湿室で行い、打設直後より 打設面を同室の空気中に開放し乾燥させた。なお、 この打設面を打設後適切な時間（本実験条件ではおおよそ 5 ～時 間) で金ごて押さえした。

b. 仕上げ材

仕上げ材として、不透湿性のA社製エポキシ樹脂系塗床材を用い た。これを材齢 $1 、 3$ (水セメント比 $60 \%$ のみ設定）、 $7 、 14 、 28$ 日に㧍いてそれぞれ塗床材 $2.0 \mathrm{~kg} / \mathrm{m}^{2}$ を打設面に塗布した。

（2）試験項目及び試験方法

\section{a. コンクリートの含水率測定方法}

ここでいうコンクリートの含水率は、コンクリートを $105^{\circ} \mathrm{C}$ で恒 量となるまで乾燥させた時、蒸発して失われた量を含水量とし、こ れを $105^{\circ} \mathrm{C}$ 乾燥で恒量となったコンクリートの質量で除した質量 含水率を指す。ただしここでは、コンクリートに埋め込んだ場合に その電気抵抗とコンクリートの質量含水率の関係が明らかとなって いるセラミックセンサ $(\phi 10 \times 5 \mathrm{~mm})$ を埋め込み、センサの電気抵 抗から質量含水率を非破壊で間接的に求めた。このセンサ及び測定 方法の詳細、精度については、文献19）を参照されたい。

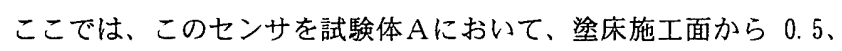
$1.5 、 2.5 、 5.0 、 7.5 、 10.0 、 13.5 \mathrm{~cm}$ の深さに埋め込み、含水率を測 定した。

b. コンクリートの細孔構造の測定

紐孔構造測定用試料は、塗床施工時（材齢 $1 、 3 、 7 、 14 、 28$

日）及び、塗床施工後コンクリート材柃56日（各塗床施工材岭及び 無乾燥の試験体）に試験体 B の乾燥面から深さ $0 \sim 1 \mathrm{~cm}$ 部分、水セ メント比 $60 \%$ の試験体では更に $2 \sim 3 \mathrm{~cm} 、 4 \sim 5 \mathrm{~cm} 、 14 \sim 15 \mathrm{~cm}$ の部 分を切り出し、2.5〜 5. $0 \mathrm{~mm}$ の粒度に調整した。次にアセトンを用い て水和を停止させ、最後に D-dry処理を行って試料を作製した。
㐮-1 コンクリートの調合表

( Air $=4.5 \%)$

\begin{tabular}{|c|c|c|c|c|c|c|c|c|c|c|c|c|}
\hline \multirow[b]{2}{*}{$\begin{array}{l}\text { スラ } \\
\text { ンプ }\end{array}$} & \multirow{2}{*}{$\begin{array}{r}\text { W/C } \\
(\%)\end{array}$} & \multirow{2}{*}{$\begin{array}{c}\text { 細骨材率 } \\
\mathrm{c} / \mathrm{a} \\
(\%)\end{array}$} & \multirow{2}{*}{$\begin{array}{l}\text { 単位水量 } \\
\left(\mathrm{kg} / \mathrm{m}^{3}\right)\end{array}$} & \multicolumn{3}{|c|}{ 總対容積 $\left(1 / \mathrm{m}^{3}\right)$} & \multicolumn{3}{|c|}{ 峃位䝷量 $\left(\mathrm{kg} / \mathrm{m}^{\mathrm{s}}\right)$} & \multicolumn{3}{|c|}{ 混和剂 $\left(\mathrm{cc} / \mathrm{m}^{\mathrm{9}}\right)$} \\
\hline & & & & $\begin{array}{l}\text { セx } \\
\text { ント }\end{array}$ & $\begin{array}{c}\text { 細骨 } \\
\text { 材 }\end{array}$ & $\begin{array}{l}\text { 粗骨 } \\
\text { 材 }\end{array}$ & $\begin{array}{l}\text { セx } \\
\text { ント }\end{array}$ & \begin{tabular}{c|} 
細骨 \\
材
\end{tabular} & $\begin{array}{c}\text { 粗骨 } \\
\text { 材 }\end{array}$ & \begin{tabular}{l|} 
No. \\
70 \\
\end{tabular} & \begin{tabular}{l|}
$\mathrm{SP}-$ \\
$8 \mathrm{~N}$
\end{tabular} & $\begin{array}{l}\text { No. } \\
303 \mathrm{~A}\end{array}$ \\
\hline 21 & 40 & 43.3 & 185 & 147 & 270 & 353 & 463 & 707 & 939 & - & 4630 & 20 \\
\hline 21 & 60 & 47.5 & 185 & 97 & 320 & 353 & 308 & 838 & 939 & 770 & - & 38 \\
\hline 21 & 80 & 49.4 & 185 & 73 & 344 & 353 & 231 & 901 & 939 & 578 & - & 40 \\
\hline
\end{tabular}

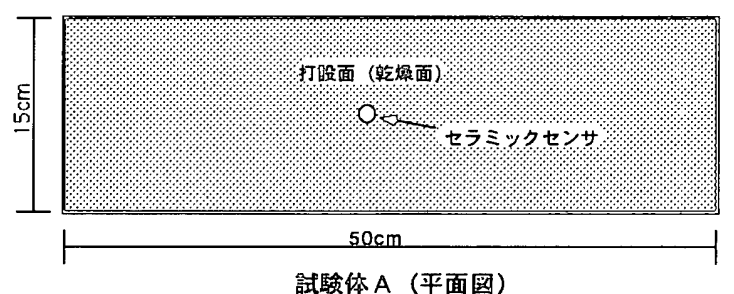

試駼体A（平面关）
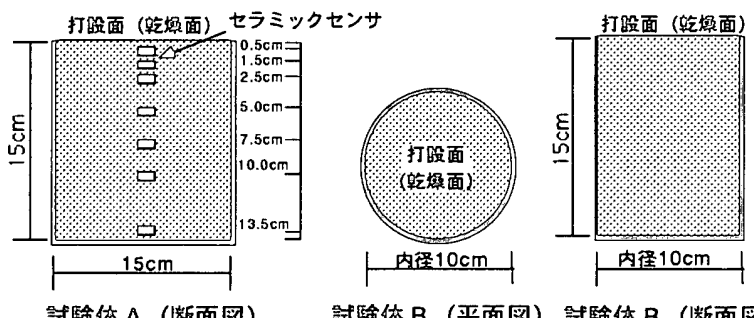

試験体 B (平面図) 試験体 B（断面図）

图-1 試酸体

この試料を水銀圧入法による細孔構造の測定に供した。測定範囲 は半径 $30 \AA \sim 3.2 \times 10^{6} \AA$ である。また、試料のセメントペースト率 （溶解率WRs $(\mathrm{g} / \mathrm{g})$ ) を、質量 $\mathrm{W}_{0}(\mathrm{~g})$ の試料を $10 \%$ 塩酸溶液中で 2 時間擋汼しセメントペースト部分を溶解させ、 $600^{\circ} \mathrm{Cで} 1$ 時間強熱 した後の不溶残分質量Wns (g) を測定し、式 (1)により求めた。

$$
\text { 溶解率WRs }=\frac{\text { 試料の質量 } \mathrm{W}_{0} \text { 一不溶残分質量Wns }}{\text { 試料の質量 } \mathrm{W}_{0}}
$$

結果は、水銀圧入法により測定された細孔量 $\mathrm{Vmp}(\mathrm{cc} / \mathrm{g})$ と式 (1) で求めた溶解率WRs $(\mathrm{g} / \mathrm{g})$ を用いて、式 (2)より硬化セメントペース

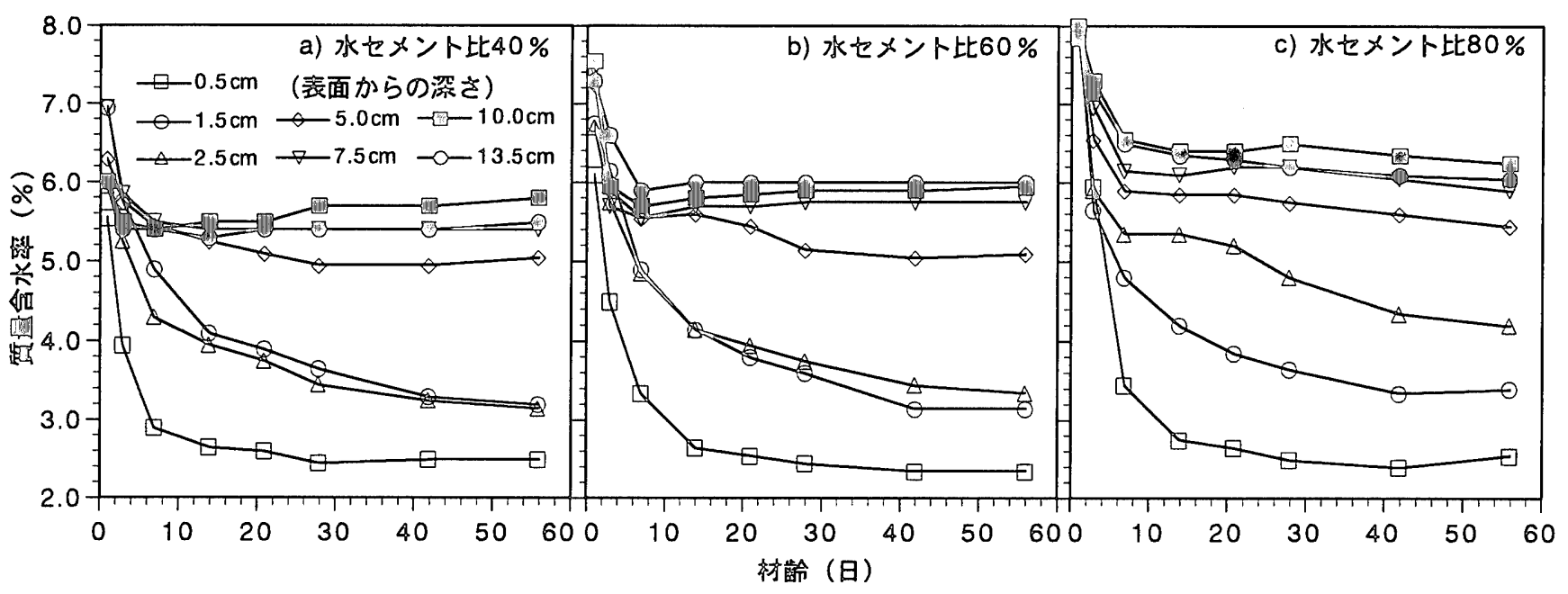

图-2乾㷧を受け繶けるコンクリートの含水率の経時变化 


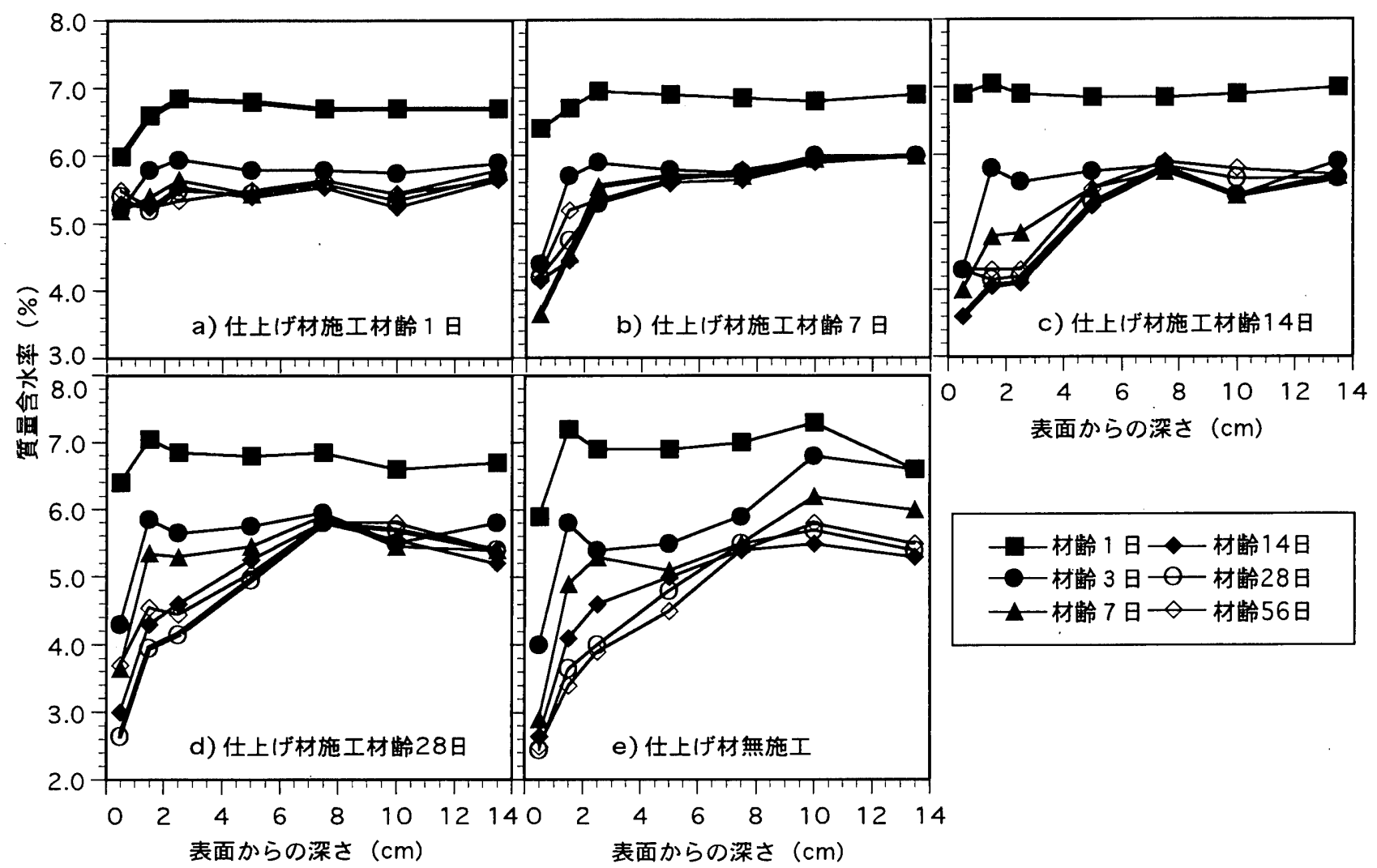

図-3（1）仕上げ材施工が含水率分布に及ぼす影響（W/C =40\%）

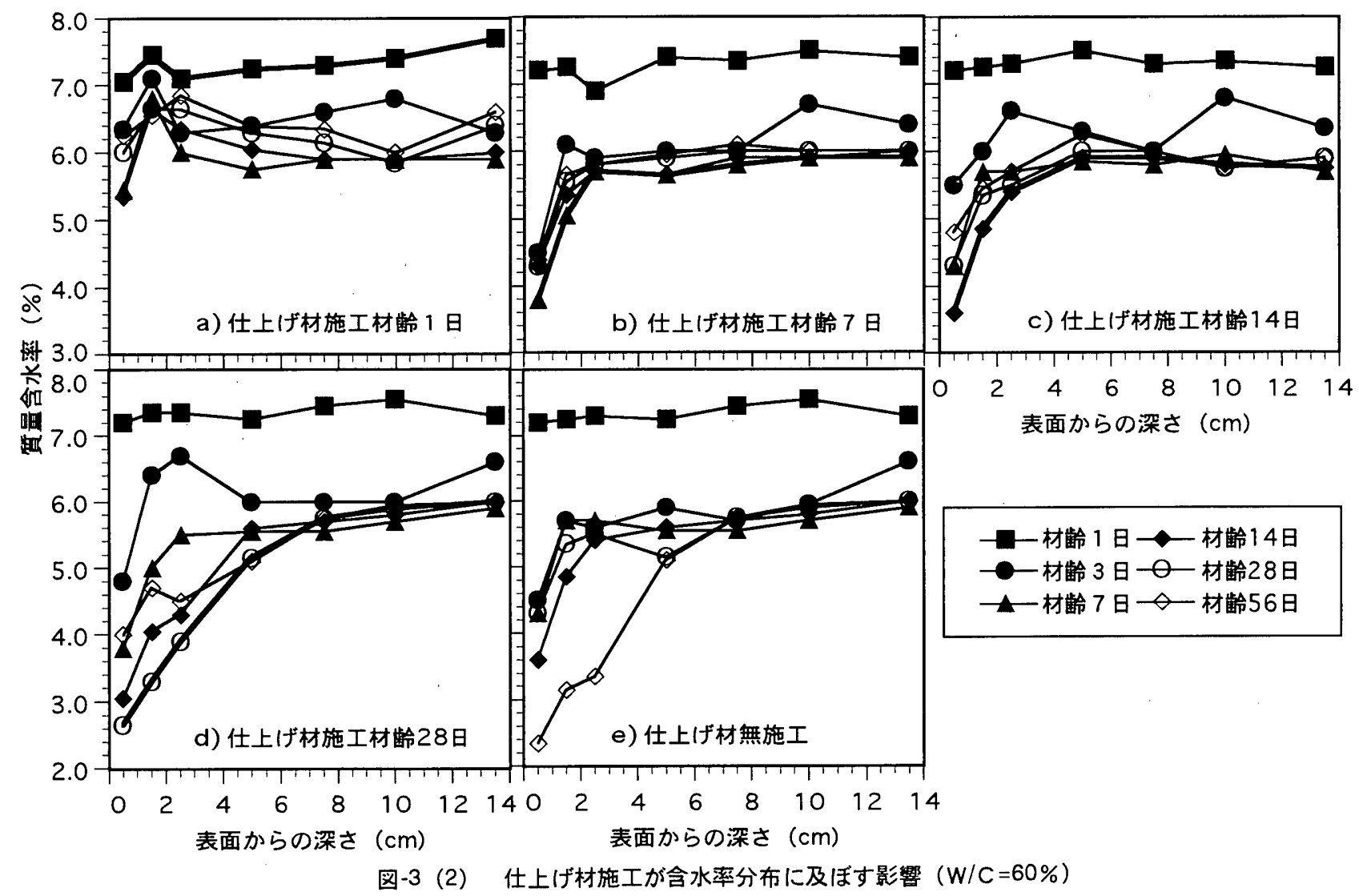

ト部分の絒孔量（有効練孔量 $\mathrm{Vep} .(\mathrm{cc} / \mathrm{g})$ ) として整理した。

有効紐孔量 $\mathrm{Vep}=\frac{\text { 試料の練孔量 } \mathrm{Vmp}}{\text { 溶解率WRs }}$
2.2 実験結果及び考察

(1) 含水率分布

図-2は打設直後より乾燥を受けるコンクリートの含水率の経時変 


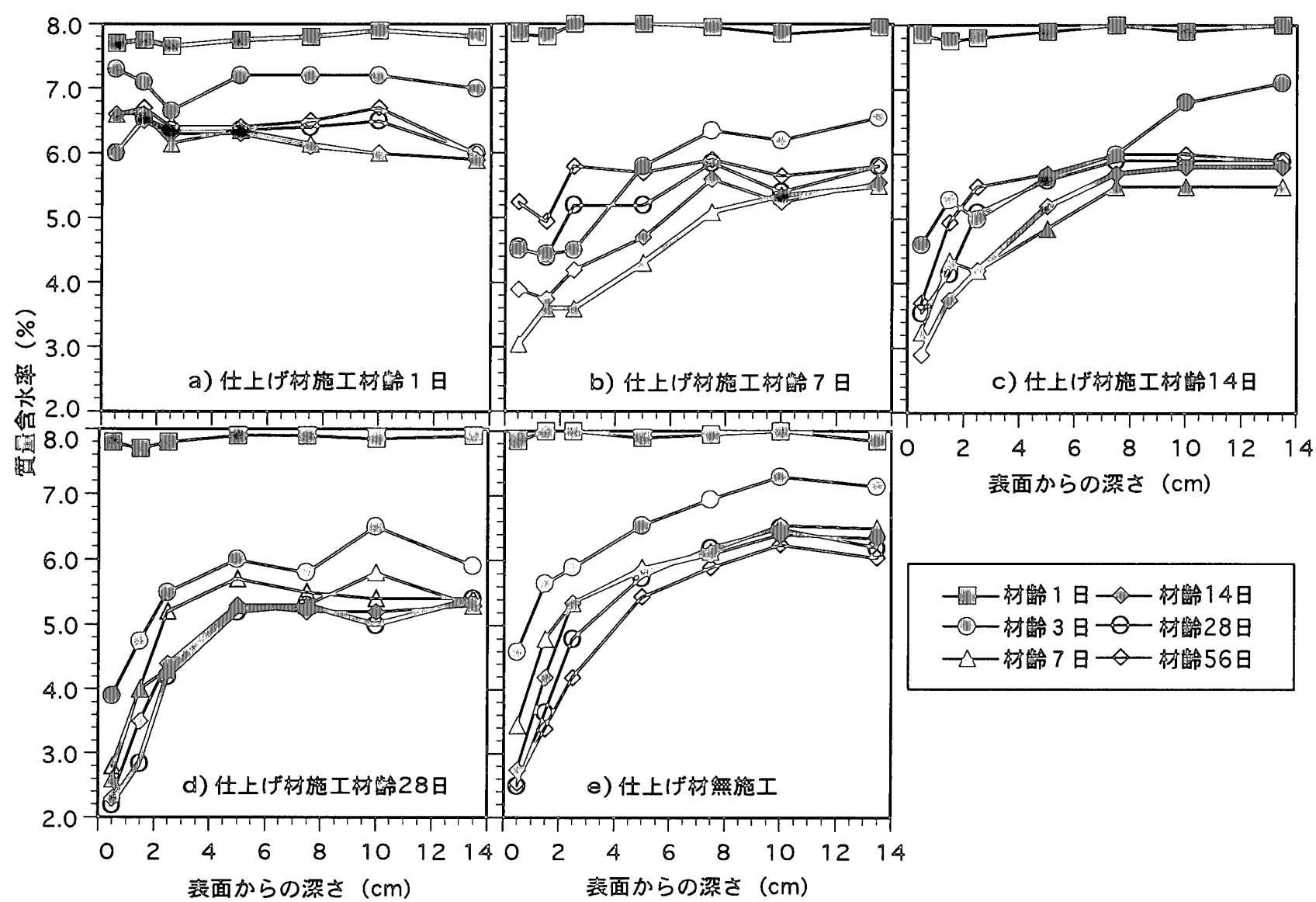

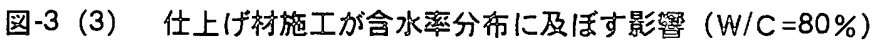

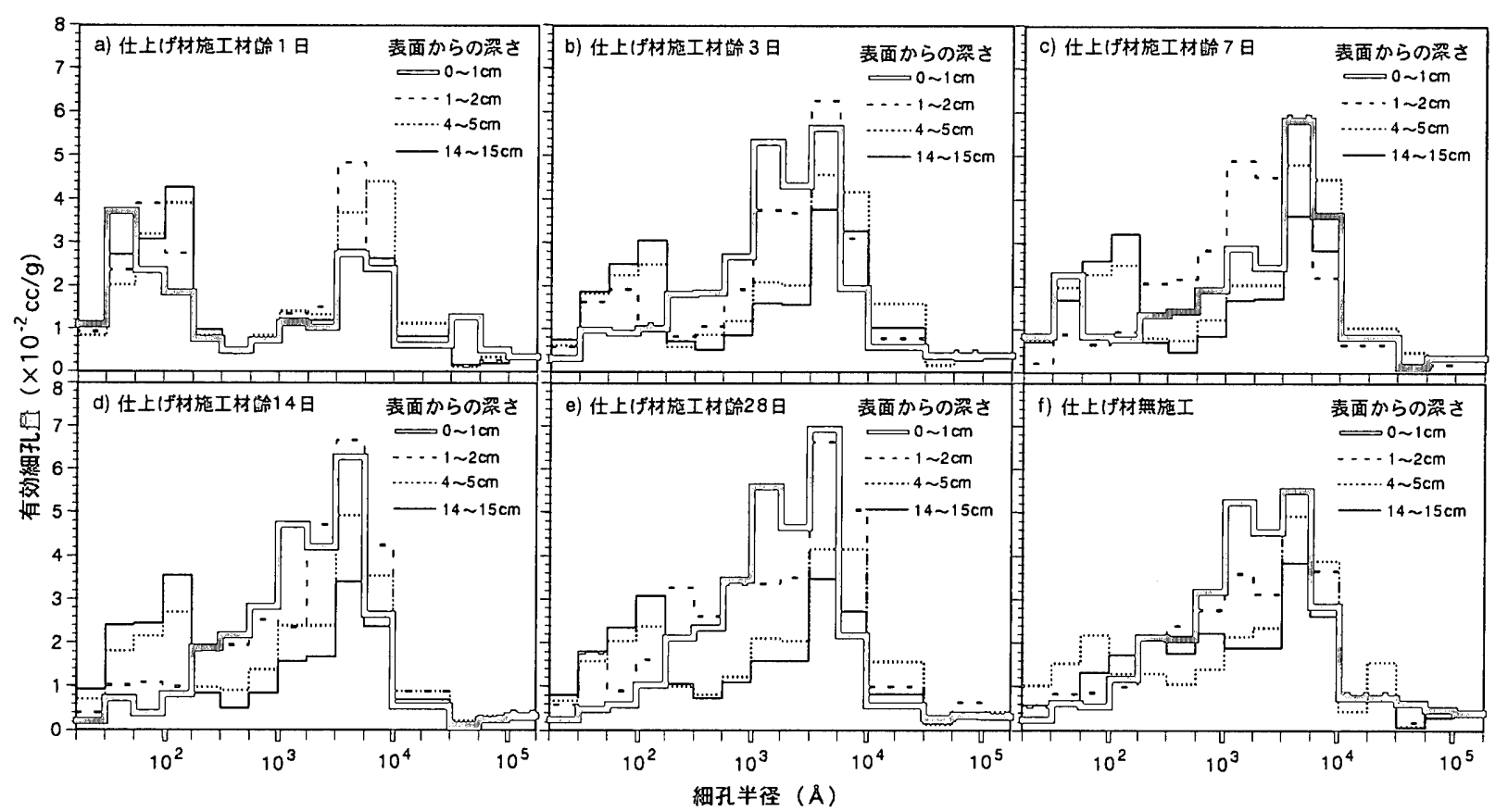

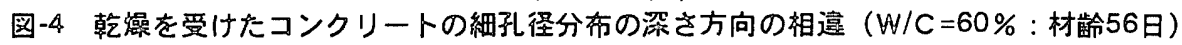

化を示したものである。表層ほど含水率の低下は早く、表層 $0.5 \mathrm{~cm}$ の含水率（口印）は材跉 7 日で3. 0 3.6\%、材齢 14 日以降は水セメ ント比にかかわらず $2.5 \%$ 前後に収束した。表層の含水率が著しく 低下するのは材齡14日程度までであることがわかる。一方 $1.5 \mathrm{~cm}$ 部 分 (O印）、2.5cm 部分（ $\triangle$ 印）の含水率は、材齢56日までなだら

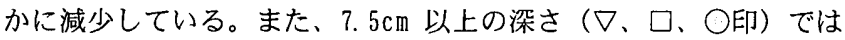

おおよそ材跲 5 日以降は大きな変化がみられず、水セメント比 $40 \%$ で5. $5 \%$ 、水セメント比 $60 \%$ で5. $8 \%$ 、水セメント比 $80 \%$ で $6.2 \%$ 前 後を示している。これらの深さでは乾燥の影響が極めて小さいこと がわかる。また、全体的に水セメント比が小さいほど、若干含水率 の低下が早くかつ含水率は小さい。これはセメントの水和による自 己乾燥のためと考えられる。 


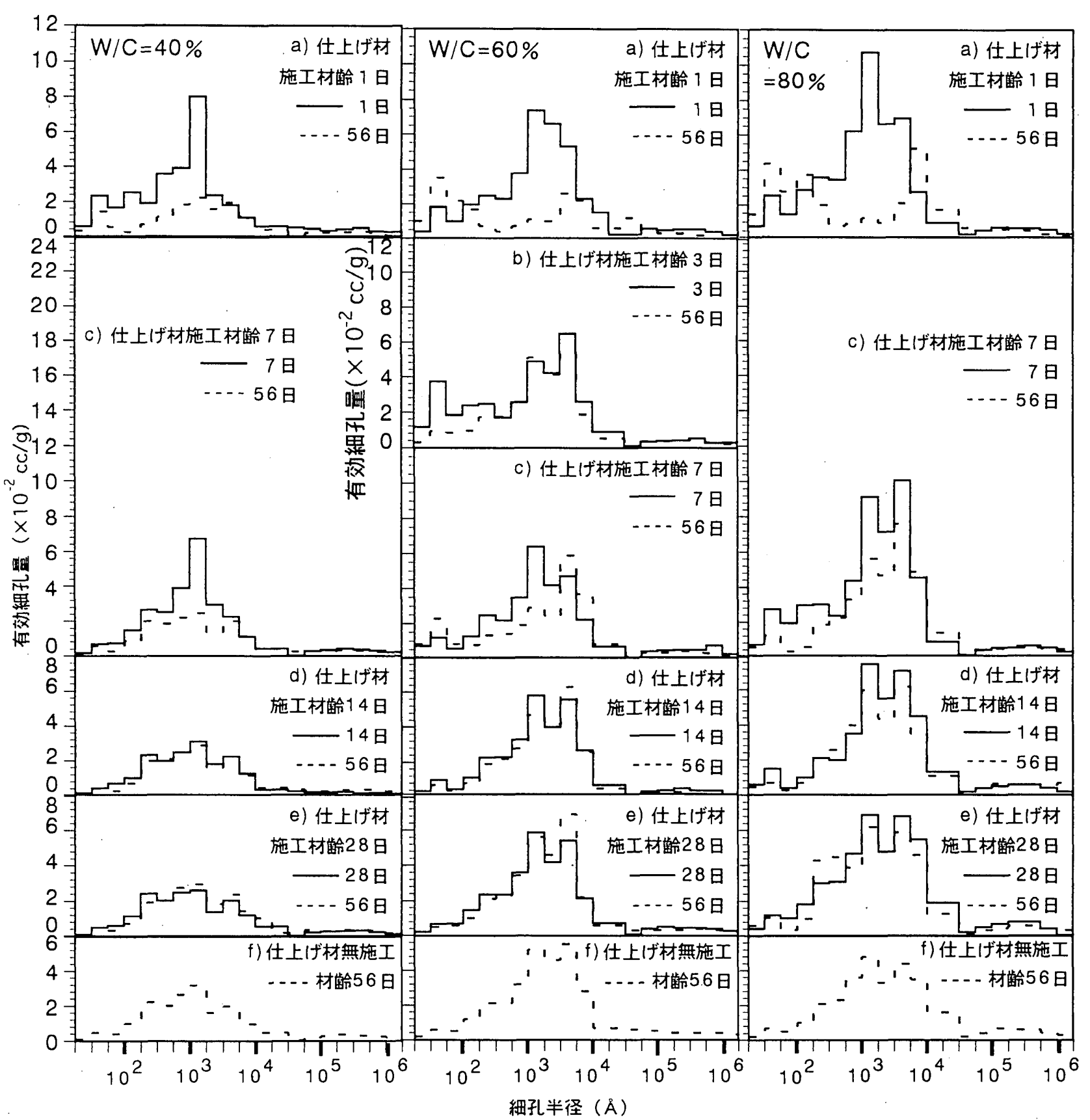

図-5 仕上げ材施工時及び材跉56日における表層0〜1cm部分の細孔径分布

b. 乾燥過程及び仕上げ材施工後の含水率分布の変化

図-3(1)〜 (3) は、表面からの深さと質量含水率の関係を水セメン ト比及び仕上げ材施工材齢ごとに示したものである。乾燥過程、す なわち仕上げ材施工前までは、打設面に近いほど含水率は低い傾向 にあり、表首から $2.5 \mathrm{~cm}$ までの含水率の低下が特に著しい。乾燥途 中で不透湿材料を施工した場合、含水率の低下はみられず、仕上げ 材施工直前の含水状態を保持している。しかしながら、若材齢で仕 上げ材を施工した場合、更に若干の含水率の低下がみられる。これ は、水セメント比が小さいほど顕著であり、前項a. でも述べたセメ ントの水和による自己乾燥によるものと理解できる。乾燥途中で不 透湿材を施工すると、施工面に近いほど時間の経過とともに含水率 が若干回復し、コンクリート内部の含水率は、均一化する傾向にあ る。これらの含水率の回復は水セメント比が大きいものほど大きい。
(2) 練孔構造

a. 仕上げ材施工材柃と紐孔径分布の深さ方向の不均質性

図-4は、水セメント比 $60 \%$ の試験体について、不透湿性仕上げ材 の施工材路ごとに、細孔径分布の打設面からの深さ方向の不均質性 を示したものである。コンクリート材路朎56日である。仕上げ材施 工材齢 1 日の試験体は、他の試験体に比し、深さ方向の紐孔径分布

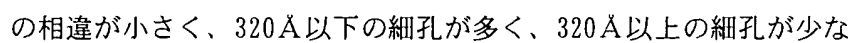
い。筆者らが行った研究 ${ }^{20)}$ では、水和が十分行われた場合、 $320 \AA$ 以下の紐孔がほとんどで、水和が不十分な場合に $320 \AA$ 以上の細孔 が多くみられることを明らかにしている。これらの研究成果を踏ま えると、仕上げ材施工材龄 1 日の試験体は、打設直後上り封かん状 態にある試験体に比べれば、 $320 \AA$ 以上の紐孔もみられるものの、 図-3で示したように高い含水状態を維持できたため水和が進んだも 


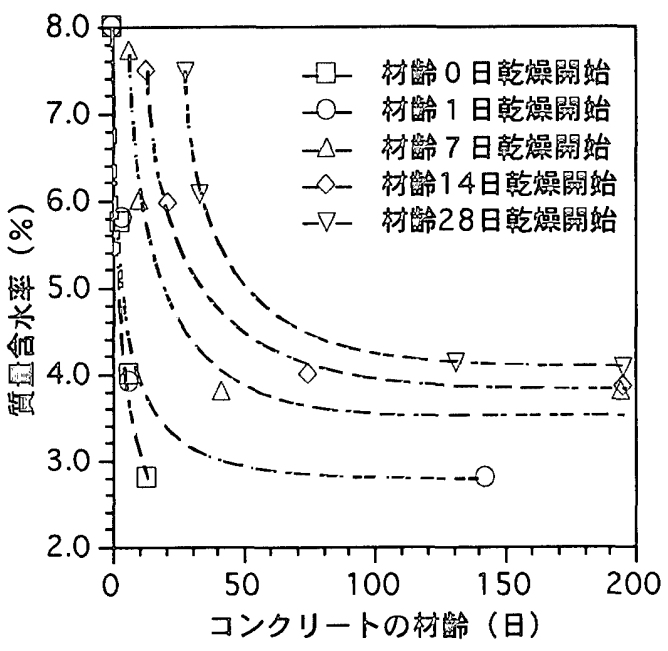

図-6 䘚層 $0.5 \mathrm{~cm}$ 部分の含水率の綏時变化
のと理解できる。材齢 3 日以降に仕上げ材を施工したものは、その 含水率分布に対応するように、打設面に近いほど水和が進まず、大 きな径の紐孔が多くみられ、表層と内部の不均質性は大きい。 b. 仕上げ材施工後の細孔構造の変化

図-5は、打設面から 0〜1 cmの表層部について水セメント比及び 仕上け材施工材龄ごとに、仕上げ材施工時（実線）と、材齢56日

（点線）における紐孔径分布を示したものである。いずれの水セメ ント比においても材齢 1 日で仕上げを施工した場合、材齢56日まで に水和に伴う細孔構造の緻密化がみられるが、仕上げ材の施工時期 の遅れに伴い両者の差は僅かなものになる。材齢 3 日で仕上げ材を 施工しても、細孔構造の緻密化があまりみられないことから、材㯝 3 日までの若材龄において、湿潤養生（含む封かん養生）を怠った 場合、その後のコンクリート表面の水和及びそれに伴う強度発現、 紐孔構造の緻密化があまり期待できないことがわかる。

更に、材齢14日以降に仕上げ材を施工した場合、仕上げ材施工時 の細孔径分布と材齢56日における細孔径分布に違いがみられず、水 和が阻害された時にみられる $320 \AA$ 以上の大きな径の細孔がそのま ま残存することがわかる。また、仕上げ材を14日（図d））、及び28 日（図e)）に施工した試験体と56日間乾燥を受け続けた試験体の細 孔径分布（図f)）に差はみられない。打設直後より14日間乾燥を受 けると、その後仕上げ材の施工等などにより密閉されても、紏孔構 造の緻密化はほとんどみられないことがわかる。

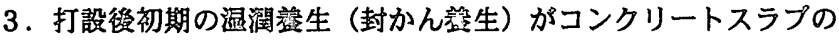

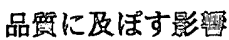

前章 2 では打設直後から乾燥を受けたコンクリートスラブの含水 率と紐孔構造を検討した。ここでは、コンクリート打設初期の湿潤 養生がコンクリートスラブの含水率、細孔構造に及ぼす影響を検討 する。なおここでは、J A S S 5 で「透水性の小さいせき板で保護 されている場合は、湿潤養生と考えてよい。」とあることから、湿 潤羑生は、透湿性の小さいビニールシートによる封かん盖生を含む。 3.1 実験の概要

（1）試験体の作製及び盖生方法

コンクリートの枋料、調合、試験体の形状は、前項 2.1の通りで

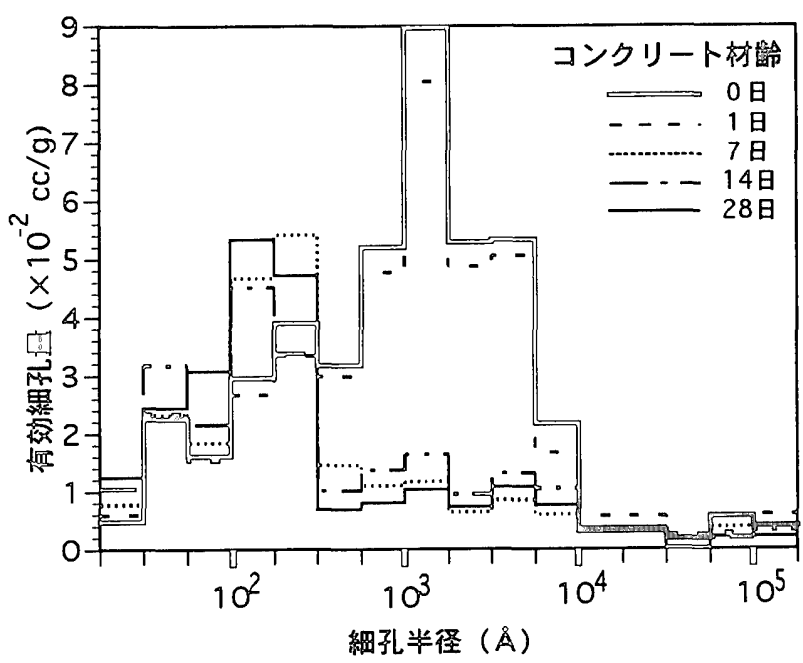

图-7乾潞關蛞時における姜層0〜1cm部分の細孔径分市

ある。ただし、水セメント比は60\%のみとした。コンクリートは、 打設直後より $20^{\circ} \mathrm{C} 、$ R. H. $60 \%$ で養生し、打設面を適切な時間（本実 験条件ではおおよそ 5 ～時間）に金ごて仕上げを行った。金ごて 押さえ終了後、試験体の打設面を透湿性の小さいビニルシートで覆 い、材齢 1、7、14、28日まで封かん養生を行った。その後 $20^{\circ} \mathrm{C}$ 、 R. H. $60 \%$ の恒温恒湿室内で乾燥させた。

（2）試験方法

含水率の測定方法、絒孔構造の測定方法は、前項 2.1 と同様に行 った。ただし、含水率は表層 $0.5 \mathrm{~cm}$ 部分を、細孔構造は表層 $1 \mathrm{~cm}$ でを対象とした。

\section{2 実験結果及び考察}

（1）表層含水率の経時変化

図-6に、コンクリートの材齢と表層 $0.5 \mathrm{~cm}$ 部分の含水率の関係を 示す。コンクリートの湿潤養生を長く行うほど、その後の乾燥によ る含水率の低下が遅くなる傾向が見られる。また、7日間以上湿潤 盖生を行った試験体は、材龄 200 日を経過しても含水率は $4 \%$ 程度 であり、これ以上含水率を低くさせることは難しいものと思われる。 これは、打設直後の湿潤養生が水和を進行させ、大きい径の細孔を 減少させる一方、小さい径の細孔を增加させ総細孔量を小さくする （図-7参照）ので、長期間湿潤盖生を行った試験体は、若材龄より 乾燥させた試験体に比し、(1)水分蒸発量が小さく、(2)乾燥環境の温 湿度と平衡なコンクリート含水量 ${ }^{21)}$ が増加したためと推察される。 （2）表層の細孔構造

図-7は、乾燥開始時の表層 $0 \sim 1 \mathrm{~cm}$ 部分の細孔径分布を示した。 乾燥の開始材齢が 0 日（試料採取は材齢 1 日）及び 1 日と、7 日以 降の試験体の間には、細孔径分布に大きな差がみられる。前者の試 験体は、後者の試験体に比し、 $320 \AA$ 以上、 $10^{4} \AA$ 以下の細孔量が多 く、320A 以下の紐孔量は少ない。これら両者の相違は、前述した 如く湿潤盖生による水和程度の差と理解できる。筆者らの行った研 究" 及び 2.2項で示してきたように、乾燥の開始ともに、紐孔構造 の緻密化は鈍くなるので、本結果は、コンクリートスラブの水和及 び細孔構造の緻密化に、いかに初期湿潤養生が大切であるかを示し たものといえよう。

ところで、筆者らが行った塗り床の接着性及びふくれに関する研 
究5)では、接着性、耐ふくれ性の確保には、下地コンクリートの乾 燥以上に、十分な水和の確保が重要であることを示している。本春 験では、残念ながら材龄 1 日と 7 日の間に乾燥の開始材柃を設けて 試験を行っていないが、筆者らが行った実験研究"によると、湿潤 養生下においても材跉 3 日では大きな練孔が残存することから、本 実験条件の範囲では、材齢 3 日から材齢 7 日の間のある時点まで、 下地コンクリートの湿潤養生を行うことで、コンクリートスラブに 要求されるおおよその水和は確保されるものと考える。その上で、 十分な乾燥を行うことが重要である。

\section{4.まとめ}

コンクリート床スラブについて、(1)打設直後から乾燥させた場合、 また(2)途中で仕上げ材を施工した場合、(3)打設初期に湿潤養生を行 った場合の含水率、細孔構造の試験結果を示し、仕上げ材を施工す るコンクリート床スラブの適正な養生の指針を検討した結果を以下 に示す。

（1）コンクリートの乾燥に伴い、特に打設面から $2.5 \mathrm{~cm}$ までの含水 率の低下が著しい。打設直後より乾燥を受ける場合打設面から 0.5 $\mathrm{cm}$ 部分の含水率は、14日以降おおよそ2.5\%に収束する。一方、7.5 $\mathrm{cm}$ より深い部分は、あまり乾燥の影響を受けず、乾燥による自己乾 燥が落ち着く 5 日以降は $6 \%$ 前後の含水率となり変化しない。

（2）乾燥途中で不透湿性材料を施工した場合、コンクリートの含水 率の低下は鈍くなり、打設面に近いほど時間の経過とともに含水率 が若干回復し、含水率は均一化する傾向がある。

（3）打設直後から乾燥を受け、材龄 1 日で仕上げ材を施工する場合 は、コンクリートの紼孔構造の緻密化が幾分期待できるが、材齢 3 日以降に仕上げ材を施す場合は、その後の細孔構造の緻密化が期待 できず、水和が不十分な時にみられる大きな径の細孔が残る。また、 材齢14日まで乾燥を受けると、その後密䦥養生しても表層部の細孔 構造はほとんど変化しない。

（4）コンクリートは、打設初期に湿潤養生を行う場合、その期間が 長いほどその後の乾燥よる含水率の低下が遅く、小さい。これは、 湿潤盖生に伴う水和の進行により、練孔構造が緻密化し、水分の蒸 発が困難になったこと、乾燥温湿度に対するコンクリートの平衡含 水量が増加したたためと思われる。

（5）強度、耐久性の観点から構造体コンクリートに要求されるセメ ントの水和と、適切な仕上げ材の下地を確保するために、打設後初 期において湿潤盖生を行い、その後乾燥させることが必要である。 本実験条件の範囲では、その必要な湿潤養生期間は高々材龄 7 日で ある。

\section{謝辞}

なお、本研究の一部は、平成 6 年度文部省科学研究費 (一般研究 （C）：代表笠井芳夫）の交付を受けて行ったものである。記して 謝意を表する。

\section{参考文献}

1）湯浅昇、笠井芳夫、松井勇：表層コンクリートの品質の評価 （乾燥を受ける表層コンクリートの細孔構造の経時変化）、日 本建築学会大会学術講演梗概集 A、pp. 199-200、1994

2）湯浅昇、鎌田英治、橋田浩 : 屋根防水層のふくれ圧力に関する
研究（下地コンクリートおよび実験環境のふくれ圧力への影 響）、日本建築学会大会学術講演梗概集 A、pp. 5 6、1988年

3）関原克章、茂呂昌男、小野正、近藤照夫：若材齢コンクリート スラブへの防水施工実験（その 4 実大施工試験の結果）、日本 建築学会大会学術講演梗概集 A、pp. 5-6、1992年

4）李翰承、呉昌熙、友澤史紀、野口貴文 : 塗膜防水材の接着性状 に及ぼす仕上げ材下地としてのコンクリートの含水状態の影響 に関する研究、日本建築学会大会学術講演梗概集 A、pp. 1289$1290 、 1994$ 年

5）湯浅昇、松井勇、逸見義男、佐藤弘和：仕上材のはがれに及ぼ す下地コンクリートの含水率、絒孔構造の影響、日本コンクリ 一ト工学協コンクリート工学年次論文報告集第18巻 第 1 号、 pp. 573-578、1996年

6）田中享二、内田昌宏、大森修、橋田浩、湯浅昇 : 塗り床のふく 㣗発生機構の一考察、日本建築学会構造系論文集、第488、pp. 25-30、1996年

7）田中享二、内田昌宏、大森修、Keesun BAE：塗り床のふくれ発 生に及ぼす下地コンクリートの影響、日本建築学会構造系論文 集、No. 493、pp. 1-7、1997年

8）丸一俊雄：プラスチック床材の接着に及ぼす下地水分の影響、 日本建築学会論文報告集、No.69、pp. 1-7、1961年

9）平井和喜、田中雅順、下田昭夫、千田清寿：コンクリート仕上 用エポキシ樹脂系塗装の付着性に関する実験研究（その 1 未乾 燥コンクリート面の塗装の付着性）、日本建築学会大会学術講 演梗概集 A、pp. 637-638、1986年

10）田畑雅幸、洪悦郎、鎌田英治：電極法によるコンクリート含水 量の測定、日本建築学会大会学術講演梗概集（構造系）、pp. 117-118、1976年

11）橋田浩、田中享二、小池迪夫：打設直後からの乾燥途中におけ るコンクリートの含水状態（仕上げ材下地としてのコンクリー トの含水状態の検討その 1 ）、日本建築学会構造系論文集、№. $412 、$ pp. 1-8、1990年

12）中山筫、佐々木正治 : 床スラブに含まれる水分の挙動、日本建 筑学会大会学術講演梗概集 A（その 1、その 2 pp. 259-262、 1991年、その 3 pp. 3-4、1992年)

13）関原克章、小野正、近藤照夫：若材涌コンクリートスラブへの 防水施工実験（その 3 下地水分の測定結果）、日本建築学会大 会学術講演梗概集 A、pp. 281-282、1991年

14）湯浅昇、田中享二、浅見勉、橋田浩：塗り床を対象とした下地 コンクリートの含水率分布及び細孔構造、コンクリート工学年 次論文報告集、Vol. 16、No. 1、pp.675-680、1994年

15）日本建築学会：建築工事慗準仕様書 - 同解説 J A S S 5 鉄筋 ב ンクリート工事、pp. 25-26、pp. 251-256、1997年

16）日本建築学会：建築工事標準仕様書 - 同解説 J A S S 8 防水工 事、pp. 2-4、pp. 55-66、1993年

17）日本建築学会：合成高分子系床仕上げ施工指針・同解説、 pp 13、pp. 169-176、1989年

18）日本建築学会：建築工事標準仕様書 - 同解説 J A S S 26内装工 事、pp. 71、1991年

19）湯浅昇、笠井芳夫、松井勇：埋め込みセラミックセンサの電気 的特性によるコンクリートの含水率測定方法の提案、日本建筑 学会構造系論文集、N0.498、pp. 13-20、1997年

20）湯浅昇、笠井芳夫、松井勇：表層コンクリートの品質の検討 （乾燥に伴う含水率分布之絒孔構造の変化）、日本建築学会大 会学術講演梗概集 A、pp. 449-450、1993年

21）近藤連一編著：多孔材料、技報堂出版、pp. 47、1973年

22）佐藤弘和、湯浅昇、逸見義男、松井勇、笠井芳夫 : 仕上材を施 す下地コンクリートの品質、日本建築学会大会学術講演梗概集 A-1、pp. 1391-1392、1995年

（1997年 7 月10日原稿受理，1997年 9 月10日採用決定） 